\title{
Influence Of Employee's Spiritual Motivation On Employee Performance (Empirical Study In Santri Works Of Taarid Tauhid Bandung Foundation)
}

\section{Iman Aryadi \& Laili Rahmawati}

STEBI Al Jabar Bandung

E-mail:_imanaryadi@gmail.com, lailirahmawati8022@gmail.com

\begin{abstract}
The development of foundations and businesses led by Abdullah Gymnastiar. The question arises as to why this business labeled with the heart of management is such a way of developing (not only becoming one of the business centers; it also becomes a "moral workshop"). Whether it is due to its leadership, work system, conducive environment, or motivation of its employees, this study aims to determine the effect of spiritual motivation on the performance of employees of the Daarut Tauhiid Foundation in Bandung. The hypothesis proposed in this study is the creed motivation, worship motivation, and muamalah motivation partially and together significantly affect performance. The subjects (samples) in this study were 33 people. The sampling method is purposive sampling. Data obtained through primary data by distributing questionnaires also added to interviews and observations. Secondary data were obtained through records and profiles of the Daarut Tauhiid foundation and information from various other sources. Data analysis was performed by multiple regression analysis. As a result, partially or together, it turns out that spiritual motivation does not affect performance. This can be seen from the $t$-count value of each variable (creed $=0.857$, worship $=0.288$ and muamalah $=0.971$ ) compared to t-table $(2.0395)$ or $\mathrm{t}$-count $<2$ and the F-count of 1.935 is smaller than 4. Alternatively, the significance level is greater than 0.05 , which is 0.14 . The lack of spiritual motivation on performance is very reasonable because spiritual motivation has become the culture and character of students of the DT foundation's work.

Another thing that should be suspected and needs serious attention is the work environment and leadership of the foundation, which needs to be changed to be more conducive and decentralized. Students of DT have fulfilled the highest spiritual need in Maslow's hierarchy. However, the need for a sense of security (work contract), physiological (primary needs), social needs (AA Gym leadership) is less fulfilled. This is very humane and human because what distinguishes it from organizations or established companies is the intention and approach.
\end{abstract}

Keywords. Religion, Spiritual Motivation, Performance.

\section{INTRODUCTION}

Much evidence states that religion influences behavior (Laurence, 1998) and can affect economic performance at the individual, group, or national level. In the book The Wealth of Nations, Adam Smith also argues that religious involvement can influence its adherents (Anderson, 1988). In fact, according to religion, Belzen is one crucial element of a culture that has influence and must be considered in the form of values, attitudes, and habits in the culture of society (Belzen, 2006).

Ethical and moral issues receive serious attention from various groups, both in developed countries and developing countries. Ethics and morals, by Western experts, are often referred to as the root of spiritualism, which is believed to be a practical guide and guide for humanity in carrying out life to not fall into ruin. Because ethics and morals prevent humans, dissuade their passion (Danah and Marshal, 2005)

In his book Spiritual Capital, Zohar Marshal provides an opening statement "change ourselves for changing the world." That is the first step that humans must do if even business life can be successful in the long term. Several studies, including those conducted, corroborated their opinion. 
By Gay Hendricks And Kate Ludeman, who examines the success of some large companies that implement ways to seek profits and spread the good in unison. The study results mentioned that of 1,435 companies that entered, there were 500 of the world's best companies. Eleven of the 1,435 companies held by 11 outstanding companies were led by Chief Executive Officers professional and humble(CEOs). 11 company leaders, on average, have a spiritual approach in controlling their business.

In addition, James Collins and Jerry Poras, two business professors from Stanford University, examined American Express, Boeing, Citicorp, General Electric, Hewlett Packard, Johnson \& Johnson, Marriot, Merck, Motorola, Procter \& Gamble, Wal-Mart, and Walt Disney. According to Sudhamek, the spirituality aspects of the companies above can be seen from the vision, mission, and fundamental values that are applied.

Besides the facts above, there are pretty exciting things in developing social problems in the West. First, there are now many courses in clinical or alcohol management based on spiritual or spiritual and religious aspects(Tonigan, 2000), not only that schools are implementing or opening "centers" of spirituality and religion (Astin, 2004). What is quite strange is the prevention of alcohol which is dangerous, but in the West, it is still allowed even though it is very detrimental to the social and social life of the community. There are counterproductive; on the other hand, they allow alcoholic drinks. On the other hand, there is alcohol therapy with spirituality and religion to cure alcohol dependence. This is one proof of spirituality that Divine Nur does not guide.

Talking about business spirituality in Indonesia, which constitutes most Muslims, Islamic religious spirituality values should have colored the business world for a long time. However, only after the reformation can make it just "work" and experience relatively rapid dynamics. Among those that became the center of attention was the Darul Tauhid boarding school phenomenon, which developed and penetrated various business segments. BAPENAS (National Planning Agency) also made the Darut Tauhid pesantren a national pilot pesantren not only because of the nuances of spirituality (religion in the strict sense), as well as its social and economic contribution to the surrounding community (Daarut Tauhid, 2004).

The business development led by Abdullah Gymnastiar is also attracting attention; various questions arise as to why the business that is "labeled" the heart of management is such that it develops, not only becoming one of the business centers, it also becomes a "moral workshop," is it really because of his leadership, work systems, a conducive environment, or the motivation of its employees.

Many factors make why a business entity or organization can succeed. However, clearly, organizational or business behavior as much as fifty percent (50\%) is influenced by psychology and social psychology (Munandar, 2002), including motivation. Therefore, the author wants to clarify the field by focusing research on the variables of spiritual motivation and employee performance of Daarut Tauhid Foundation by taking the title "The Effect of Employee Spiritual Motivation on Employee PerformanceSpiritual (Empirical Study of Employees on PP Daarut Tauhid Foundation)."

\section{LITERATURE REVIEW THEORETICAL FOUNDATION}

Term and religion are different, but some people associate it with religion. In the context of Indonesia, quoting Muhammad Lawi Yusuf and Syahmuharnis and Harry Sidharta turned out to be spiritualists in the context of the Muslim Ummah usually and associated with religion. As for references or research related to spirituality or religion with quite a lot of performance or economy (Yusuf, 2007).

Some previous studies related to spiritual motivation and performance include a dissertation by Wibisono (2002). The variables used are aqidah, worship and muamalah variables. Research conducted in the industry in Batamindo manufacturing industry employees concluded that spiritual motivation influences spiritual motivation: aqeedah, worship and muamalah on religious performance, although in this study, The motivational variable of worship has a negative influence on religious performance

(Muafi, 2003). Another study conducted in Surabaya (with the same variables) in the Muslim industrial area of Rungkut, produced a conclusion that strengthens Wibisono's research that muamalah motivation has a 
dominant influence on religious performance. However, what distinguishes it is that the worship variable turned out to have a positive influence. This Muafi study was conducted on different employees, namely operational employees, and non-operational employees, and the results turned out to be no difference between the two types of employees. This provides evidence that even non-operational employees feel the importance of spiritual motivation in improving their religious performance.

Other research related to spiritual motivation and performance is research conducted by Abdussalam DZ regarding religious attitudes and productivity of small entrepreneurs in Cirebon; his research concludes that religious attitudes (partially or simultaneously) have a strong relationship with entrepreneur productivity in small industries in the Cirebon district (Salam, 2004).

Overseas research is in the form of off-field research, companies, even national levels, including Marcus Noland, Religion, Culture and Economic Performance with variables as follows: total factor productivity, per capita growth, religiosity, culture, need to achieve, power distance index, uncertainty avoidance index, individualism-collectivism index, masculine-feminine index long-term orientation index, raised religiously, attends religious services at least once a week, and does not believe in God. This research was conducted in several countries. His research concludes that there are correlations between religious affiliation, the intensity of religious beliefs, and indicators of cultural tendencies (Nolan, 2007).

\section{PREVIOUS RESEARCH}

Below is a summary of research regarding religion and spirituality summarized by the author:

Tabel 1. The List of Previous Research

\begin{tabular}{|c|c|c|}
\hline & $\begin{array}{l}\text { Researcher Research } \\
\text { Theme }\end{array}$ & $\begin{array}{l}\text { Information } \\
\text { Methods, Variables etc. }\end{array}$ \\
\hline 1 & $\begin{array}{l}\text { Wibisono, Chablullah } \\
\text { The Effect of Spiritual Motivation on } \\
\text { Employee Performance in } \\
\text { Manufacturing Manufacturing Sub } \\
\text { Sector in Batamindo Batam } \\
2005\end{array}$ & $\begin{array}{l}\text { Questionnaire } \\
\text { Interview } \\
\text { (Independent Variable) } \\
\text { Motivation Aqeedah, Motivation of Worship, } \\
\text { Motivation of Mu'amalat } \\
\text { (Dependent Variable) } \\
\text { Religious Performance } \\
\text { Structural Equation Modeling (SEM) } \\
\text { Second-Order Confirmatory } \\
\text { motivation of aqidah has a direct positive effect } \\
\text { on religious performance, worship has a negative } \\
\text { direct effect on religious performance, Mu'amallat } \\
\text { has a positive direct effect on religious } \\
\text { performance, the influence of aqidah, worship, } \\
\text { mu'amallat on employee performance obtained } \\
\text { work, and productive results are dominant }\end{array}$ \\
\hline 2 & $\begin{array}{l}\text { Abdussalam D } \\
\text { Religious Attitudes and Productivity of } \\
\text { Small Entrepreneurs in Cirebon } \\
2004\end{array}$ & $\begin{array}{l}\text { Questionnaire } \\
\text { (Independent Variable) } \\
\text { Knowledge, Understanding, Practicing } \\
\text { (D) dependent Variables) } \\
\text { Productivity -Profitability } \\
\text { Regression } \\
\text { There is a relationship between religious attitudes } \\
\text { (partial/simultaneous) with productivity }\end{array}$ \\
\hline 3 & $\begin{array}{l}\text { Marcus Noland } \\
\text { Religion, Culture, and } \\
\text { Economic Performance }\end{array}$ & Data Cross Section \\
\hline
\end{tabular}




\begin{tabular}{|c|c|c|}
\hline & & $\begin{array}{l}\text { Total Factor Productivity, Per Capita GDP } \\
\text { Growth Religiosity, Culture, Need to Achieve, } \\
\text { Power Distance Index Index, Uncertainty } \\
\text { Avoidance Index, Individualism-Collectivism } \\
\text { Index, } \\
\text { Masculine-Feminine Index } \\
\text { Long-term Orientation Index, } \\
\text { Raised Religiously, } \\
\text { Attends Religious Services at Least } \\
\text { Once a Week, } \\
\text { Does Not Believe in God, } \\
\text { Regulations } \\
\text { there are correlations between religious } \\
\text { affiliations, the intensity of religious affiliations } \\
\text { beliefs, and indicators of cultural tendencies }\end{array}$ \\
\hline 4 & $\begin{array}{l}\text { Bali Endangered Paradise? Tri Hita } \\
\text { Karana and the Conservation of the } \\
\text { Island's Biocultural Diversity } \\
\text { Anak Agung Gede Agung }\end{array}$ & $\begin{array}{l}\text { Multivariate Regression } \\
\text { Analysis of the Canonical Correlation } \\
\text { of Bali Culture Has Headed to Erosion. Hub. } \\
\text { Humans with Nature } 60 \% \text {. With Humans } 40-45 \% \text {. } \\
\text { Humans with } 90-95 \%\end{array}$ \\
\hline 5 & $\begin{array}{l}\text { Spiritual Leadership and } \\
\text { Organizational Performance: An } \\
\text { Exploratory Study } \\
\text { Louis W Fry and Laura L. Matherly } \\
\text { Tarleton State University }\end{array}$ & $\begin{array}{l}\text { Questionnaire } \\
3 \text { Dimensions Spiritual Leadership and two } \\
\text { dimensions: spiritual survival/wellbeing Vision, } \\
\text { Altruistic Love, Hope / Faith, Meaning / } \\
\text { Calling, Membership, Organizational } \\
\text { Commitment, Productivity,\% Sales Growth, } \\
\text { Distributor Profit } \\
\text { The Amos 4.0 SEM } \\
\text { (Structural Equation Modeling) }\end{array}$ \\
\hline 6 & $\begin{array}{l}\text { Religion in Macroeconomics "A } \\
\text { Quantitative Analysis of Weber's } \\
\text { Thesis Tiago V Cavalcanti, Stephen } 1 \\
\text { Parente, Rui Zhao } \\
2003\end{array}$ & $\begin{array}{l}\text { Technology, Endowments, Preferences, } \\
\text { Demographics. Competitive Equilibrium: Profit } \\
\text { Maximization, Utility Maximization, Market } \\
\text { Clearing } \\
\text { Econometrics }\end{array}$ \\
\hline 7 & $\begin{array}{l}\text { Spiritual Leadership and Strategic } \\
\text { Scorecard Model of Performance } \\
\text { Excellence: The Case of Tomasso } \\
\text { Corporation } \\
\text { Laura L. Matherly, Ph.D. Tarleton } \\
\text { State University } \\
\text { matherly@ tarleton.edu } \\
\text { Louis W. Fry, Ph.D. Tarleton State } \\
\text { University-Central Texas } 1901 \text { South } \\
\text { Clear Creek Road Killeen, TX } 76549 \\
\text { lwf@ tarleton.edu } \\
\text { J-Robert Ouimet, Ph.D. OCB Inc. } \\
\text { Holding Chairman and CEO and } \\
\text { Ouimet-Tomasso Inc. Jourimet- } \\
\text { ocb@ @c.aira.com }\end{array}$ & $\begin{array}{l}\text { Questionnaire } \\
\text { Spiritual Leadership } \\
\text { Vision } \\
\text { Hope / Faith } \\
\text { Altruistic Love } \\
\text { Spiritual Survival / Well_Being } \\
\text { Meaning / Calling } \\
\text { Membership } \\
\text { Organizational Outcomes } \\
\text { Organizational Commitment } \\
\text { Productivity }\end{array}$ \\
\hline
\end{tabular}




\begin{tabular}{|c|c|c|}
\hline 8. & $\begin{array}{l}\text { Spirituality at Work: An Exploratory } \\
\text { Sociological Investigation of The Ford } \\
\text { Motor Company } \\
\text { Timothy James Bowman } \\
\text { A Thesis Submitted in Partial } \\
\text { Fulfilment of Requirements for the } \\
\text { degree of Doctor of Philosophy. } \\
\text { The London School of Economics and } \\
\text { Political Science } \\
2004\end{array}$ & $\begin{array}{l}\text { Grounded theory approach } \\
\text { One on One Structured Qualitative Interviews } \\
\text { Extensive one-on-one unplanned discussion } \\
\text { Extensive participant observation and } \\
\text { ethnography } \\
\text { The Inclusion of the Result of selective } \\
\text { independent corporate studies } \\
\text { Spiritual family help to understand the reality of } \\
\text { industrial organization as a practice at Ford }\end{array}$ \\
\hline 9. & $\begin{array}{l}\text { Spirituality at Work: } \\
\text { A Conceptualization and Measure of } \\
\text { Donde P. Ashmos \& Dennis Duchon } \\
\text { Division of Management \& Marketing } \\
\text { at the University of Texas at San } \\
\text { Antonio } \\
\text { San Antonio, Texas 78249-0634 210- } \\
458-5377\end{array}$ & $\begin{array}{l}\text { Questionnaire } \\
\text { three-dimensional conceptualization of spirituality } \\
\text { the inner life, meaningful work, and community } \\
\text { the Maximum Likelihood extraction method with } \\
\text { a varimax rotation }\end{array}$ \\
\hline 10 & Spiritual leadership (Fry, 2003) & $\begin{array}{l}\text { Vision Hope / Faith Altruistic Love: Trust / } \\
\text { Loyalty Forgiveness / Acceptance / Gratitude } \\
\text { Integrity Honesty Courage Kindness Empathy / } \\
\text { Compassion Patience / Meekness / Endurance / } \\
\text { Excellence Fun }\end{array}$ \\
\hline 11. & $\begin{array}{l}\text { Workplace spirituality (Giacalone \& } \\
\text { Jurkiewicz, 2003) }\end{array}$ & $\begin{array}{l}\text { Honesty Forgiveness Hope Gratitude Humility } \\
\text { Compassion Integrity }\end{array}$ \\
\hline 12 & $\begin{array}{l}\text { Religion (Smith, 1991; Kriger \& } \\
\text { Hanson, 1999) }\end{array}$ & $\begin{array}{l}\text { The vision of Service / Letting Go of Self } \\
\text { Honesty Veracity / Truthful -ness Charity } \\
\text { Humility } \\
\text { Forgiveness Compassion Thankfulness / Gratitude }\end{array}$ \\
\hline 13. & $\begin{array}{l}\text { Character ethics \& education } \\
\text { (Josephson, 2002) }\end{array}$ & $\begin{array}{l}\text { (Trustworthiness) Honesty, Integrity, Reliability } \\
\text { (Promise Keeping) Loyalty, Respect, Civility, } \\
\text { Courtesy, Decency, Dignity, Autonomy, } \\
\text { Tolerance, Acceptance } \\
\text { (Responsibility) accountability } \\
\text { Excellence Diligence } \\
\text { (Perseverance) Continuous, Improvement } \\
\text { (Fairness) Equity impartiality Caring Citizenship } \\
\text { Process }\end{array}$ \\
\hline 14. & $\begin{array}{l}\text { Positive psychology (Snyder \& Lopez, } \\
\text { 2001) }\end{array}$ & $\begin{array}{l}\text { Optimism, Hope Humility Compassion, } \\
\text { Forgiveness Gratitude, Love, Altruism, Empathy, } \\
\text { Toughness, Meaningfulness, Humor, }\end{array}$ \\
\hline 15. & $\begin{array}{l}\text { The Effect of Work Motivation on } \\
\text { Employee Performance with Spiritual } \\
\text { Work Ethic Moderator Variables: } \\
\text { Empirical Studies in PT Semen Gresik } \\
\text { (Persero) Tbk }\end{array}$ & $\begin{array}{l}\text { Maslow's motivation theory, namely the theory of } \\
\text { human needs, which includes: Physiological } \\
\text { needs (physiological needs), Security and safety } \\
\text { needs (security needs and work safety), Social } \\
\text { needs (social needs), Esteem needs (needs of } \\
\text { appreciation), and Self-actualization needs (self- } \\
\text { actualization needs). In contrast, the concept of } \\
\text { performance is based on the quantity of work, } \\
\text { quality of work, job knowledge, creativity, } \\
\text { cooperation, dependability, initiative, and } \\
\text { personnel qualities. }\end{array}$ \\
\hline
\end{tabular}


Review of Islamic Economics and Finance (RIEF) Volume 2, Number 2, December 2019

\begin{tabular}{|l|l|l|}
\hline & The spiritual work ethic that researchers make as a \\
& & \\
& & \\
\hline
\end{tabular}




\begin{tabular}{|l|l|l|}
\hline & $\begin{array}{l}\text { moderating variable is based on the value of } \\
\text { honesty (shiddiq), trust (Amanah), } \\
\text { intelligence } \\
\text { (Katonah), delivery of truth (tabligh). }\end{array}$ \\
\hline
\end{tabular}

Research regarding employee and company performance has been carried out, assessments and indicators are built based on the theory and character of the research object. For example, the thesis, "the influence of work motivation and organizational culture on the performance of social workers in the social service technical unit of the East Java province." Performance measurement is based on quality of work, quantity, knowledge, reliability, attendance and cooperation. Then Ahmad Rajaul Masrur in his thesis entitled "Dimensions Analysis of Employee Performance Evaluation of Bank Syariah Mandiri Employees in the East Java Region has performance indicators following characters such as loss, namely daily transactions, customer service, culture of nature, work quality, reliability, problem solving, initiatives, cooperation, communication and discipline.

This research is a replication of Wibisono and Muafi's research. It is a recommendation from previous research looking for a work atmosphere that is sufficient or considered very thick with religious nuances to be observed more realistically. DT approaches these criteria; the indications can be seen from the vision, mission, programs, and culture. Judging from the previous research site, it turned out to be done at a public company or not based on religion. Based on the variables, there are differences The dependent variable is changed to employee performance because religious performance is multidimensional and very broad. Another difference from the data collection methods from this study is the existence of interviews and observations that are useful in deepening the observation of phenomena in the field.

\section{HYPOTHESIS}

Based on the theory, which states that spiritual motivation is the highest requirement. Similarly, previous research states that the motivation of faith, worship, and muamalah has a positive effect on both partial and joint performance, then the hypothesis proposed as follows:

1. There is a positive and significant effect between faith motivation on the performance of employees of Daarut Tauhiid foundation.

2. Positive and significant influence between religious motivation on the performance of employees of Daarut Tauhiid foundation.

3. Positive and significant influence between muamalah motivation on the performance of employees of Daarut Tauhiid foundation.

4. Based on the positive and significant influence between the motivation of aqidah, worship and muamalah on the performance of employees of the Daarut Tauhiid foundation.

\section{RESEARCH METHODOLOGY}

There are three independent variables and one dependent variable, among the three independent variables namely aqeedah, muamalah and Ibadan, while one independent variable is employee performance.

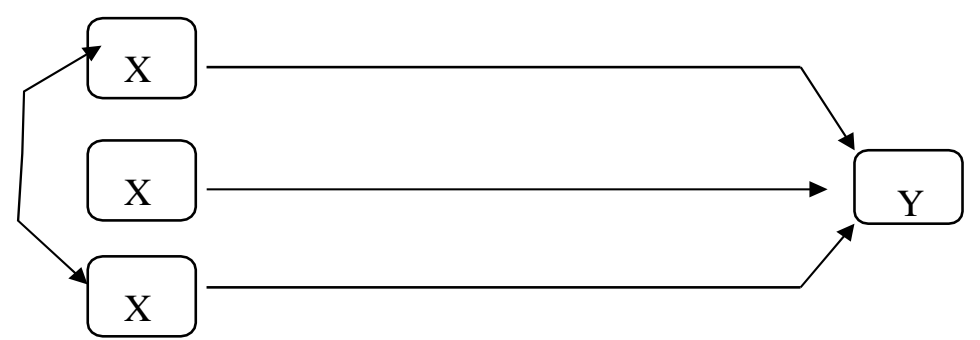

Figure 1 Relationship Between Variables 
Remarks:

$\mathrm{X} 1=$ Aqidah

$\mathrm{X} 2$ = Worship

$\mathrm{X} 3$ = Muamalah

$\mathrm{Y}=$ Employee Performance

This study is a recommendation from previous research looking for a good work atmosphere or considered very thick with the nuances of his religion so that more can be observed more realistically. The employee (Santri Karya Foundation) Darut Tauhiid (DT) approaches these criteria. DT Foundation is located in Gegerkalong Girang Bandung 4015.

The model used in analyzing data is in the form of Multiple Linear Regression. The purpose of this analysis is to determine the effect of independent variables on the dependent variable. Data processing hypothesis testing results with statistical tests are carried out, namely: Simultaneous test (F test) and partial test (t-test).

\section{DISCUSSION}

Multiple Linear Regression

Tests Testing of research hypotheses is carried out to prove whether the data obtained supports or does not support the provisional allegations submitted.

Tabel 2. Results of Multiple Linear Regression Model Estimation

\begin{tabular}{|c|c|c|c|c|c|}
\hline $\begin{array}{l}=0.414 \text { F-cour } \\
=0.172 \text { DW-c } \\
\text { dj. } R^{2}=0.083\end{array}$ & $\begin{array}{l}=1 \\
\text { unt } \\
g=\end{array}$ & $\begin{array}{l}5 \\
.980 \\
47\end{array}$ & & & \\
\hline Model & & B & t-count & t-table & Sig. \\
\hline (Constant) & & 17,180 & 0,683 & 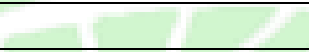 & 0,501 \\
\hline Aqidah & - & 0,539 & 0,857 & Sig. $5 \%=2.0395$ & 0.399 \\
\hline Worship. & 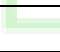 & 0.164 & 0.288 & Sig $5 \%=2.0395$ & 0.776 \\
\hline Muamalah. & & 0.370 & 0.971 & Sig $5 \%=2.0395$ & 0.340 \\
\hline
\end{tabular}

Source: Data processed (Appendix)

From the results of the data processing above, then the equation can be made as follows:

$$
Y=\mathrm{a} 17,180+0.539 X_{1}+0.164 X_{2}+0.370 X_{3}
$$

1. Testing the First Hypothesis

From the results of the analysis data of multiple linear regression models can be seen from the tvalue of the creed variable of 0.857 compared to t-table (2.0395) or t-count $<2$, partially the variable is not significant.

2. Second Hypothesis Testing

From the results of data analysis of multiple linear regression models, the t-value of the worship variable of 0.288 compared to t-table (2.0395) or in other words t-count $<2$, partially the variable is not significant.

3. Testing the Third Hypothesis

The results of data analysis of multiple linear regression models can be seen from the t-value of each variable muamalah of 0.971 compared to $\mathrm{t}$-table (2.0395) or $\mathrm{t}$-count $<2$ then the variable is not significant.

4. Testing the Fourth

Hypothesis The fourth hypothesis states that the motivation of aqeedah, muamalah, and worship together influence the performance of employees of the Daarut Tauhiid Foundation. 
The data analysis of multiple linear regression models shows that the F-count of 1.935 is more minor than four or the significance level is more significant than 0.05 , which is 1.935 , so the fourth hypothesis is not proven.

\section{CLOSING}

\section{Conclusion}

Based on the results of data analysis and hypothesis testing, the compiler can draw the following conclusions; The results of multiple linear regression analysis proved that spiritual motivation did not affect employee performance. This is indicated by an F-count of 1.935 less than four or a significance level greater than 0.05 , which is 0.147 . The spiritual, motivational factors possessed by students of the

DT Foundation's work include faith motivation which is the motivation of faith in God, faith in the book of God, faith in the Rasul of Allah. Muamalah motivation covers primary needs, secondary needs, and work and produce. The motivation of worship includes the level of practice of prayer, prayer, and fasting.

Partially or together, it turns out that spiritual motivation does not affect performance. This can be seen from the $t$-count value of each variable (creed $=0.857$, worship $=0.288$ and muamalah $=0.971$ ) compared to t-table (2.0395) or t-count $<2$ and the F-count of 1.935 is smaller than 4 . Alternatively, the significance level is greater than 0.05 , which is 1.935 .

It is strongly suspected that spiritual motivation does not affect performance because environmental factors are not conducive. The environment that is not conducive is the accumulation of employee rationalization, the fall of turnover, unclear work contracts, and the condition of the foundation in the transition period so that all these things psychologically affect the motivation and performance of an employee in the management of 2002-2007.

Another strong allegation that needs attention academically serious is a spirit that has become a DT foundation culture. The formula for spirituality, if applied to other institutions with different backgrounds, will have different results. It is different from previous research in companies with general and plural backgrounds so that usually religious matters are highly responsive. It can be concluded that students of DT have fulfilled the highest spiritual need in the Maslow hierarchy

However, in the case of research at DT that needs serious attention is looking for factors of work environment and leadership of the foundation, which needs to be changed to be more conducive and decentralized. Physiological (primary needs) and social needs (AA Gym leadership) are all factors that affect performance. The motives or intentions of the three needs are very human and are human nature but what distinguishes between conventional theories with Islam is the way of approach and intention.

\section{Suggestion}

1. For the management of the Darul Tauhiid Foundation

Even though Darut Tauhiid is a foundation, the management must clarify the contractual agreement with the students because the student is a core part of the ongoing business process. A human resource that is very influential on the organization's efforts in achieving organizational goals, the continuity of da'wah, and DT's contribution to the people and religion. Therefore there is a need for communication and transparency between leaders and students of works.

\section{For Daarut Tauhiid Foundation}

AA Gym is very influential on the foundation. The very centralistic foundation model must immediately be slowly changed into exciting propaganda concepts but not to someone anymore. Technically all the attributes related to AA Gym must be immediately reduced and replaced by other figures who have achievements. The concept of preaching, training and education DT is more valuable and can contribute more to the broader community.

3. For further researchers 
For researchers who will conduct research related to spiritual motivation and performance, it is necessary to include other factors, and also further expand the object of research by using companies that have a for researchers who will conduct research related to spiritual motivation and performance 
is necessary to include other factors and further expand the object of research by using companies with a more significant number of employees. It is also important to consider technical research conducive to researchers and especially the momentum being investigated.

\section{REFERENCE}

Al-Qur'ān / Tafsir

Abdul Hamid Mursi, SDM yang Produktif : Pendekatan Al-Quran dan Sains Cet-I, Jakarta: GIP, 1997.

Abdul Hamid Mursi, SDM yang Produktif: Pendekatan Al-Qur'an-Quran dan Sains, alih bahasa Moh Nurhakim, Cet ke-IV, Jakarta: GIP, 1999.

Abuy Sodikin dan Badruzaman, Metodologi Studi Islam, Bandung: Tunas Nusantara, 2000.

Agus Widarjono, Ekonometrika: Teori dan Aplikasi untuk Ekonomi dan Bisnis, Yogyakarta: Ekonosia, Fakultas Ekonomi UII.

AL-Fanjari, Pengarahan Islam tentang kesehatan, Sicincin: al-Hidayah,1990.

Algifari, Analisis Regresi, Yogyakarta: BPFE, 1999.

Helmi, Avin Fadilla, Beberapa Teori Psikologi Lingkungan, Buletin Psikologi Tahun VII, No, 2 ( Desember 1999)

Atang Abdul Hakim dan Jaiz Mubarok, Metodologi Studi Islam, Cet 3, Bandung: Rosda, 2000.

Danah Zohar dan Ian Marshal, Spiritual Capital, Cet. ke-1, Bandung: Mizan, 2005.

Deliarnov, Perkembangan Pemikiran Ekonomi, Jakarta: Raja GrafindoPersada,1997.

Djaka Sutapa, Agama dan Pembangunan, Pandangan Kristen dalam Moralitas Pembangunan Persfektif dalam Agama-agama dalam pembangunan, Cet-I, Yogyakarta: Pustaka Pelajar,1994.

Djamaludin Ancok dan Fuat Nashori Suroso, Psikologi Islami; Solusi Islam Atas Problem-problem Psikologi, Cet VI, Yogyakarta: Pustaka Pelajar, 2005.

Endang Saifudin Anshari, Wawasan Islam ; Pikiran-pikiran pokok tentang Islam dan Umatnya, Cet.Ke-3, Jakarta: Rajawali, 1993.

Imam Ghozali, Aplikasi Analisis Multivariate dengan Program SPSS, Semarang: UNDIP, 2005..

Iqbal Hasan, Analisis Data Penelitian dengan Statistik, Jakarta: Bumi Aksara, 2004.

Irawan Soehartono, Metode Penelitian Sosial, cet. ke-4, Bandung: Remaja Rosdakarya, 2000.

Mannan, Teori dan Praktek Ekonomi Islam, Yogyakarta: Dana Bhakti Wakaf,1995.

Masri Singarimbun, Metode Penelitian Survei, Jakarta: LPE3S, 1989.

Mathis dan Jackson, Manajemen Sumber Daya Manusia, Jakarta: Salemba Empat, 2002.

Miftah Farid, Pokok-Pokok Ajaran Islam, cet.ke-7, Bandung:Pustaka,1995.

Nataatmadja, Intelegensia Spiritual, Jakarta:Perenial Press, 2001. 
Rahman, Doktrin Ekonomi Islam, Jakarta: Dana Bhakti Wakaf,1997.

Robert Kreitner dan Angelo Kinicki, Perilaku Organisasi, alih bahasa Erly Suandy, Jakarta: Penerbit Salemba Empat, 2003.

Singgih Santoso, Buku Latihan SPSS Statistik Parametrik, cet. ke-3, Jakarta: Elex Media Komputindo, 2002.

Sugiyono, Metode Penelitian Bisnis, cet. ke-6, Bandung: Alfabeta, 2004.

Suharsimi Arikunto, Prosedur Penelitian Suatu Pendekatan Praktek, Edisi Revisi IV Cetakan 11 Jakarta: Rineka Cipta, 1998.

Sukanto Reksohadiprojo dan T. Hani Handoko, Organisasi Perusahaan, Teori Struktur dan Perilaku, Yogyakarta: BPFE, 2000.

Supardi, Metode Penelitian Ekonomi Dan Bisnis, Yogyakarta :UII Pres ,2005.

Syahmuharnis dan Harry Sidharta, Transcendental Quotient, cet. Ke-1, Jakarta: Republika, 2006.

T. Hani Handoko, Manajemen: edisi kedua, Yogyakarta: BPFE Yogyakarta, 2001.

Thabbarah, Ruh Shalat Dimensi Fikih dan Kejiwaan, Jakarta: Pustaka Al-Kaustar, 2001.

Thaha, Kedokteran dalam Islam, Surabaya: Bina Ilmu, 1983.

Thahir Ibnu Shalih Jazairi, Jawahiru al-kalamiyah, Surabaya: Muhamad Ibnu Ahmad bin Nabhan.

Wahid Sulaiman, Jalan Pintas Menguasai SPSS 10, Yogyakarta: ANDI, 2002.

Yusuf Al Qardhawy, Niat dan Ikhlas, cet.ke-13, Jakarta Timur: Pustaka al-Kaustar, 2005. 